\title{
THE IMPACT OF LEGAL AND VOLUNTARY INVESTOR PROTECTION ON THE EARLY ADOPTION OF INTERNATIONAL FINANCIAL REPORTING STANDARDS (IFRS)****
}

\author{
BY \\ ANNELIES RENDERS* AND ANN GAEREMYNCK**
}

\begin{abstract}
Summary
Prior studies explain the early adoption of International Financial Reporting Standards (IFRS) by firm-specific benefits. However, IFRS adoption also leads to increased disclosure and reduced accounting choices, resulting in a loss of private benefits for company insiders. This paper argues that this loss depends on characteristics of the institutional environment (i.e. the level of investor protection). We find that in countries with strong laws or extensive corporate governance codes IFRS is more likely adopted as the loss of private benefits for company insiders is smaller. Furthermore, corporate governance recommendations are as effective as laws in stimulating IFRS adoption and become more important when laws are weaker.
\end{abstract}

Key words: corporate governance, IFRS adoption, legal investor protection, private benefits of control

\section{INTRODUCTION}

Growth in international trade and capital flows and a rising cross-border economic integration over the past two decades have led to the desire to harmonise accounting standards across countries. In Europe, a harmonisation process started in the seventies and eighties with the publication of a number of EC Directives (Council of the European Commission (EC) $(1978,1983)$ ). A major step in this harmonisation process has been taken in 2005 with the adoption of the International Financial Reporting Standards (IFRS) by all listed companies in the European Union. The decision to oblige listed companies to use IFRS from 2005 onwards was taken by the European Commission in 2000 (EC (2000)). Immediately after this decision in 2000, a number

\footnotetext{
* Department of Accounting and Information Management, Maastricht University, P.O. Box 616, 6200 MD Maastricht, The Netherlands, e-mail: a.renders@aim.unimaas.nl

** Department of Accounting, Finance and Insurance, Catholic University of Leuven, Naamsestraat 69, 3000 Leuven, Belgium.

*** We thank the FWO for the financial support (FWO-project G.0244.02). We gratefully acknowledge the comments of the participants of the 26th Annual European Accounting Association Congress in Seville (2003), and of the International Accounting Section Mid-year Conference of the American Accounting Association in San Diego (2004). We acknowledge the comments of the discussant and participants of the Accounting Research Day in Antwerp (May 2004). Special thanks go to M. Willekens, J. Suys, and W. Landsman and two anonymous referees.
} 
of countries, such as the Netherlands and Austria, allowed companies to use IFRS as an alternative for the local standards in order to smoothen the changeover to IFRS in 2005. Some other countries, such as France, Belgium, Germany and Italy, already permitted listed companies to follow IFRS before the decision by the EC in 2000. ${ }^{1}$ As a result, a number of European companies were already using IFRS before it became mandatory in 2005. These companies are called 'early adopters'.

The purpose of this study is to investigate the determinants of early IFRS adoption in Europe. ${ }^{2}$ Documenting these determinants is important as it provides insights into the costs and benefits associated with the mandatory switch to IFRS in 2005.

Prior studies investigating the determinants (Cuijpers and Buijink (2005); La Porta et al. (1998); El-Gazzar et al. (1999)) focused on the benefits of IFRS adoption, assuming that company insiders' incentives are irrelevant. However, the choice for IFRS also results in costs for company insiders (e.g. majority shareholders and managers). As the adoption of IFRS is associated with an increase in disclosure and a decrease in the number of accounting method choices (Ashbaugh (2001); Ashbaugh and Pincus (2001); Leuz and Verrecchia (2000)), it leads to a decline in managerial discretion and a loss of private benefits for company insiders. Fewer opportunities to manage earnings under IFRS make it more difficult to divert assets from the company, influence the performance related bonus or sell assets below their market value to majority shareholders. In this study, we explicitly incorporate these costs as they may offer an explanation why only $15 \%$ of the EU companies have adopted IFRS in 2002 (PwC (2002)). ${ }^{3}$

The decrease in private benefits of control will however not be the same in all countries. Recent empirical work has found that the value of private benefits is negatively associated with the level of investor protection provided by countries (Dyck and Zingales (2004); Nenova (2003)). We hypothesize that company insiders have a higher cost of adopting IFRS in countries with weak investor protection as the reduction in private benefits after IFRS adop-tion is larger in these countries. Although the literature typ-

1 These countries have allowed the use of IFRS since 1998.

2 Early or voluntary adoption refers to the fact that companies have adopted IFRS before it became mandatory in 2005. This terminology is consistently used in prior studies (Cuijpers and Buijink (2005); Dumontier and Raffournier (1998); El-Gazzar (1999)) and indicates that companies could choose to follow IFRS before 2005. In this study, it actually boils down to studying the determinants of the use of IFRS in 2001.

3 The increase in disclosure following IFRS adoption may also lead to proprietary costs. However, given the high level of private benefits (Coffee (2001); Dyck and Zingales (2004)) and the concentrated ownership structures (La Porta et al. (1998)) in the countries under study, we believe that loss of private benefits constitutes the largest cost associated with the adoption of IFRS. Nevertheless, we do include in our model proprietary costs as possible determinants of IFRS adoption, but we do not find significant results. This indicates that proprietary costs do not restrain companies from adopting IFRS. 
ically focuses on legal investor protection (La Porta et al. (1998)), we also consider a measure of voluntary investor protection, measured by the extensiveness of corporate governance recommendations, as a characteristic of the institutional environment.

This study thus contributes to the literature by investigating IFRS adoption from an insider perspective and by linking the decrease in private benefits of control to characteristics of the institutional environment. To our knowledge, our study is the first to document a relation between corporate governance codes and the choice of accounting standards. Furthermore, this study provides insight into the relation between managerial opportunism and company decisions, which in turn have an impact on the transparency in capital markets. Finally, our study provides evidence on how the costs of mandatory IFRS adoption differ across countries.

Using a sample of 1563 European companies that are allowed to use IFRS in 2001, we find that firms are more likely to adopt IFRS in 2001 when investor protection is strong, i.e. when the decrease in insiders' private benefits from IFRS adoption is small. The results also show that laws and recommendations are equally effective in curbing private benefits of control and thus in enhancing the likelihood of IFRS adoption. Furthermore, we find that corporate governance recommendations and laws serve as substitutes as the impact of corporate governance recommendations on the early adoption of IFRS is larger in countries with weak laws. Finally, when we look at specific corporate governance recommendations and laws, we find that not all recommendations have an impact on IFRS adoption. Corporate governance recommendations with regard to specific shareholder rights, such as the one share/one vote rule, have no significant impact on the adoption of IFRS, although laws prescribing the same rights do.

The remainder of this paper is organized as follows. In section 2 we give an overview of the existing literature and develop the hypotheses. Section 3 specifies the data collection and defines the model and variables. Section 4 presents the results and some robustness tests. Finally, the main conclusions are summarized in section 5 .

\section{LITERATURE REVIEW AND HYPOTHESES}

Recently, a big step in the harmonization process of accounting has been taken as listed companies in the European Union have to use International Financial Reporting Standards (IFRS) from 2005 onwards for their consolidated financial statements. The introduction of these international standards has a number of consequences. It leads not only to companies using the same accounting standards across countries, but also to a higher accounting quality in Europe. Compared to most local accounting standards of Continental 
European countries, IFRS requires more disclosure of information and limits the amount of accounting choices available to managers (Ashbaugh (2001); Ashbaugh and Pincus (2001); Leuz and Verrecchia (2000)). As a consequence, IFRS leads to less accounting discretion and hence curbs the private benefits insiders can extract from the company.

This reduction in private benefits of control following IFRS adoption can be rather substantial since most Continental European countries are characterized by concentrated ownership structures (La Porta et al. (1997, 1998)). Prior literature has established that the private benefits of control are considerably high in countries with concentrated ownership structures (Dyck and Zingales (2004); Nenova (2003)). For example, in Italy, the average value of control is worth $37 \%$ of the equity value of the firm (Dyck and Zingales (2004)).

Consequently, company insiders in these countries tend to have a preference for poor firm transparency in order to protect their private benefits of control. The more accurate and detailed the accounting information is, the more difficult it is for an insider to expropriate value without incurring legal penalties or reputational costs (Ferrell (2004)). This is evidenced by the findings of La Porta et al. (2004) that an increase in mandatory disclosure requirements is associated with a substantial decrease in the level of private benefits. Also Dyck and Zingales (2004) show that the level of disclosure negatively influences the private benefits insiders can extract. They find that one standard deviation increase in disclosure reduces the value of control by $9 \%$.

The amount of private benefits insiders have to give up after adopting IFRS will depend on the level of investor protection offered by countries. According to Benos and Weisbach (2004), the most important factor explaining the level of private benefits is the legal environment in which the company operates. In countries with extensive investor protection, private benefits of control are already curbed independent of the accounting standards used (Coffee (2001); Leuz et al. (2003)). For instance, Nenova (2003) and Dyck and Zingales (2004) find that the value of private benefits is lower in countries with better laws protecting investors. As a result, in countries with strong legal shareholder protection, the costs of adopting IFRS are low as insiders have few private benefits. For instance, Leuz et al. (2003) find that the level of earnings management, through which insiders try to hide their expropriation, is lower in countries with strong investor protection, as insiders have less to hide. A number of other studies (e.g. Ali and Hwang (2000); Ball et al. (2000); Hung (2001)) show that in countries with weak investor protection, the accounting quality and transparency is lower. ${ }^{4}$

4 This is also consistent with the literature on the decision of companies to cross-list in the US. Doidge (2004) finds that after cross-listing in the US, the private benefits decrease and this decrease is larger for companies from countries with weak investor protection. The reason is that by cross-listing, companies have to comply with more stringent disclosure requirements and are subjected to stronger laws protecting investors. 
Therefore, our first hypothesis is formulated as follows:

$\mathrm{H1}$ : There is a positive association between the extent to which laws protect shareholders and the early adoption of IFRS.

In this paper we also include a feature of the institutional environment not yet studied, namely the comprehensiveness of corporate governance recommendations. The recent accounting scandals, such as Enron, Worldcom and Ahold, have given rise to various initiatives to develop national and international corporate governance codes. Many of these corporate governance codes, such as the OECD Principles of Corporate Governance (1999), state that the corporate governance framework should ensure the disclosure of timely and accurate information. Most codes also formulate recommendations with regard to the rights of shareholders, such as the right to appoint management. Finally, corporate governance improves the monitoring of company insiders by, for instance, recommending the presence of independent directors on the board of directors. Therefore, extensive corporate governance recommendations may reduce the level of expropriation by insiders. So corporate governance recommendations can be seen as a measure of voluntary investor protection $^{5}$ and based on the same reasoning as for laws protecting investors, we hypothesize:

$\mathrm{H} 2$ : There is a positive association between the extensiveness of corporate governance recommendations and the early adoption of IFRS.

Furthermore, as corporate governance recommendations are not mandatory and can not be enforced by any authoritative body, we expect that their effect on IFRS adoption is smaller than the effect of laws.

H3: The impact of corporate governance recommendations on the early adoption of IFRS is smaller than the impact of laws protecting shareholders.

Finally, we also formulate a hypothesis with respect to the relation between corporate governance recommendations and laws protecting investors. According to Black (2001), alternative sources of protection become more important if legal rules are too weak to provide protection. In countries with weak laws protecting investors, the private benefits for insiders are high. In these countries extensive corporate governance recommendations, as an alternative for laws, could lead to companies being less inclined to extract value, even though laws protecting investors are lacking. So, we expect laws and recommendations to serve as substitutes.

$\mathrm{H} 4:$ The impact of corporate governance recommendations on the early adoption of IFRS increases as laws protecting investors become weaker.

5 We designate corporate governance recommendations as the level of voluntary investor protection because in Europe companies are not required to follow these recommendations, which is in contrast to the US where corporate governance is mandated by laws. 
3 DATA AND METHOD

\subsection{Data}

Our sample consists of all the listed companies from EU countries that allow the choice between local GAAP and IFRS for domestic and foreign companies in 2001. ${ }^{6,7}$ Our sample thus comprehends companies listed in seven EU Member States, namely Austria, Belgium, Denmark, France, Germany, Italy and the Netherlands. This leads to an initial sample of 2,594 listed companies (see Table 1). Of these 2,594 companies, 213 or $8 \%$ use IFRS. The following companies are then removed from the sample: companies listed on the German New Market, ${ }^{8}$ companies reporting according to US GAAP, companies with missing data on the control variables, and outliers. A sample of 1,563 companies remains, of which 110 companies $(7 \%)$ voluntarily report according to IFRS in $2001 .^{9}$

In order to investigate the impact of laws protecting investors and corporate governance recommendations on the early adoption of IFRS, we develop two indices. First, we construct a corporate governance index $\left(\mathrm{CGI}_{j}\right)$ measuring the extensiveness of corporate governance recommendations in each country based on the OECD Principles of Corporate Governance (1999) and the Comparative Study of Corporate Governance Codes published by the European Commission in 2002. Our index consists of 50 recommendations (see Appendix 1) which are grouped into five categories: general principles, principles concerning the board of directors, board committees, shareholders, and disclosure. These 50 recommendations are a selection from the OECD principles so that we have a good balance between transparency and completeness. We use the OECD principles as a benchmark because they are widely accepted and referred to. ${ }^{10}$ We select, however, only the principles that can be straightforward interpreted as pro-investors. Other studies drawing up corporate governance ratings for companies include largely the same principles and subcategories (e.g., Black et al. (2006); Drobetz (2003); Beiner et al. (2006); Gompers (2001)).

6 We use the total sample of listed companies and not a matched sample because matching will lead to an overclassification of IFRS companies and as a result to biased estimators (Zmijewski (1984)).

72001 was the latest year with financial information when we started this study.

8 Companies listed on the New Market segment of the German Market are obliged to submit their financial statements using either IFRS or US GAAP.

9 We verified from the hard copies that companies following IFRS according to Datastream effectively stated compliance with IFRS in their audit report.

10 For instance, the World Bank uses these principles as a benchmark to draw up country corporate governance assessments. Also the IMF and the International Corporate Governance Network (ICGN) subscribe to the principles of the OECD. 
EARLY IFRS ADOPTION

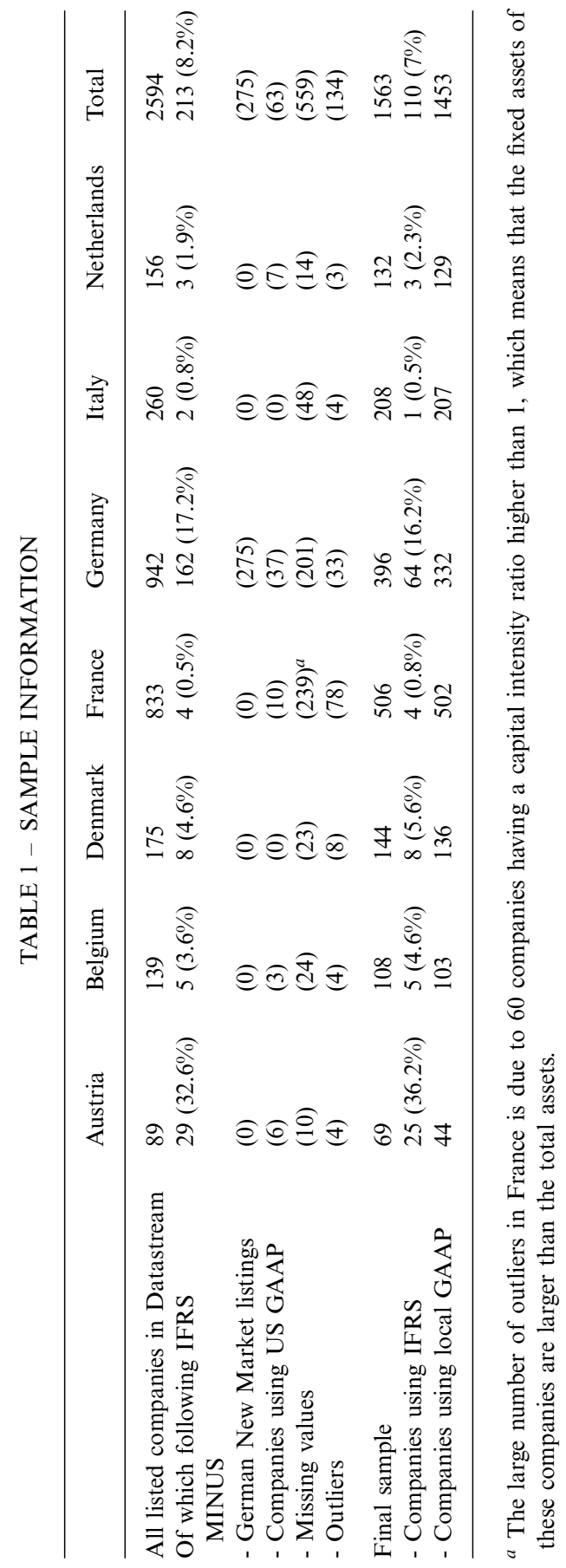


To score the countries on this index, we use the Comparative Study of Corporate Governance Codes of all EU countries published by the EC (2002). ${ }^{11}$ The scoring of the index is simple: a principle is either present in a country code (YES, score equals 1 ) or not (NO, score equals 0$).{ }^{12}$ We sum all scores and rescale the scores on the categories to 1 so that each category has an equal weight in the total score of the index. ${ }^{13}$

Second, we develop a measure for the extensiveness of legal shareholder protection in a country (LAW2001 $j$ ). We update a shareholders' rights index originally developed by La Porta et al. (1998). This original index is a combination of 7 shareholder rights based on the company law and commercial code of countries in 1993 and is the first to quantify the extent of laws protecting investors. ${ }^{14} \mathrm{We}$ do not only update this index but also extend it to make it more in line with recent changes in laws and with our corporate governance index. Our law index for 2001 comprehends 27 principles classified under three categories: board of directors, shareholders and disclosure (see Appendix 2).

In contrast to La Porta et al. (1998), we are only looking at laws in civil law countries, which consist of bright-line rules. Compared to common law countries, which are more principle based, judges in civil law countries are not supposed to go beyond the statutes. This special feature of civil laws makes it easy and straightforward to quantify the laws. Again, we only include principles that can be interpreted as pro-investors. The scoring method is the same as with our corporate governance index. ${ }^{15}$

Table 2 reports descriptive statistics of our two indices. Panel A presents the scores on the corporate governance index. Germany has the highest score on the corporate governance index (0.525), followed by Belgium (0.452). In contrast, Austria has no corporate governance recommendations in 2001. When we take a look at the categories of the corporate governance index, we see that large differences occur between countries. For instance, Belgium attaches a lot of value to principles on the board of directors (0.794), while

11 Only corporate governance codes that are published before January 2001 are taken into account. This means that we measure the extensiveness of corporate governance recommendations at the beginning of our sample period.

12 For some principles, such as the independence of the board of directors (principle 15) and of the board committees (principles 27 to 32 ), the score can be $0,0.5$, or 1 . The score equals 1 if a code recommends that the majority of directors or members of the committees should be independent. The score is equal to 0.5 if independence is only required for a minimum number of directors. If this topic is not covered by the codes or if the number of independent members is not specified, the score is 0 .

13 Our results are robust to using other ways of weighing the principles and categories.

14 The index covers, for instance, ease of participation in corporate voting and legal protection against expropriation by management.

15 As a robustness check, we used in the regressions the original index developed by La Porta et al. (1998). The results become slightly less significant. We also applied other weighing schemes and find that our results are robust. 
EARLY IFRS ADOPTION

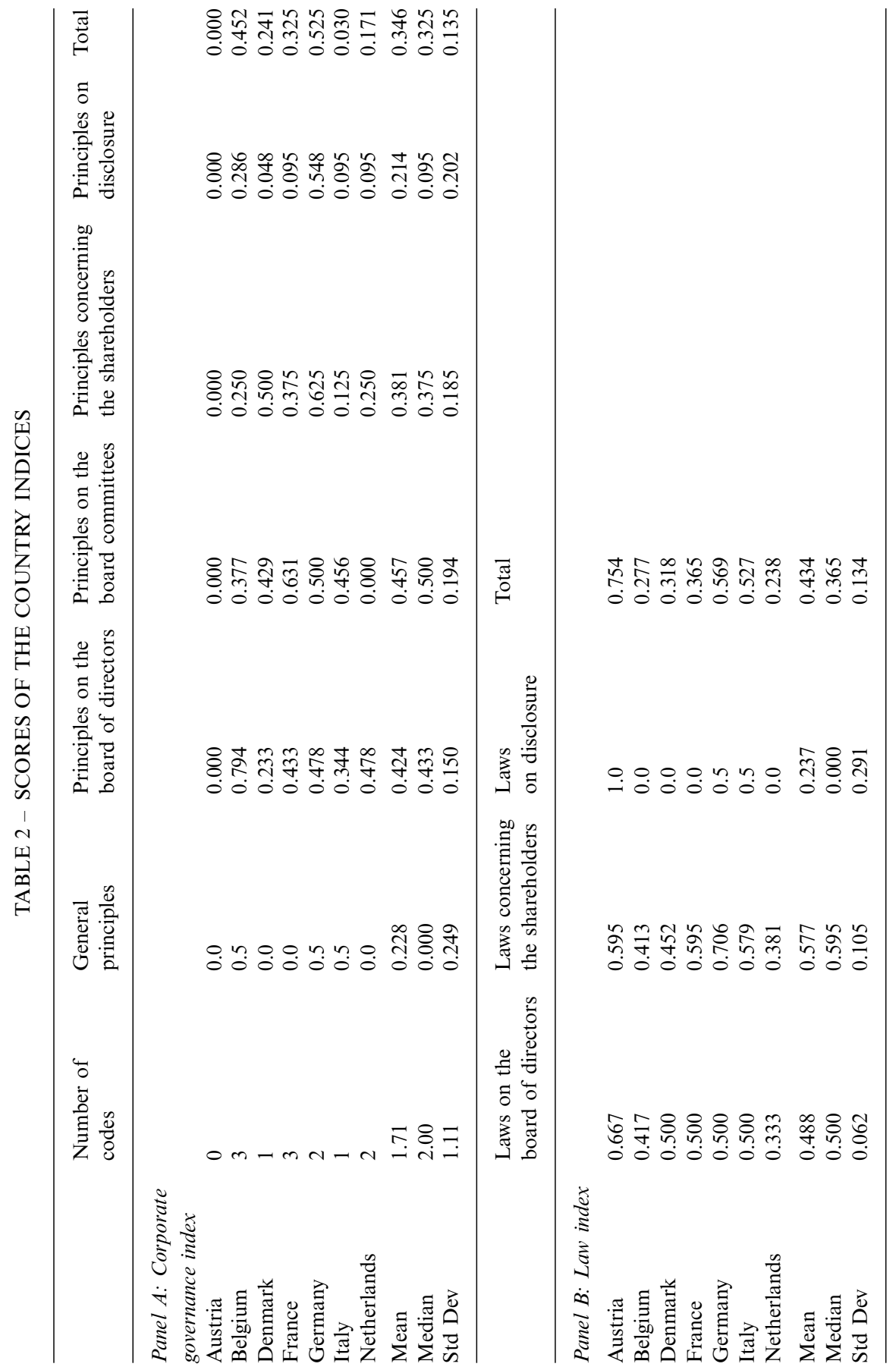


France focuses on board committees (0.631). Finally, Germany stresses in its corporate governance codes the importance of shareholders (0.625) and of disclosure (0.548).

Panel B presents the scores of the countries on the law index. Austria has by and large the best legal shareholder protection (0.754), followed by Germany (0.569). So the two countries with the most companies following IFRS (see Table 1) also have the strongest shareholder protection, either through corporate governance recommendations or through laws. As is the case with the corporate governance index, Germany emphasizes the protection of shareholders in its laws (0.706). Austria scores the highest on the other two categories, namely board of directors (0.667) and disclosure (1.0).

\subsection{Model and variable definitions}

Estimation is done by means of a logistic regression with Rogers (1993) standard errors. A logistic regression is a technique for analysing the effects of a number of explanatory variables on a dichotomous dependent variable. However, different from prior studies (Cuijpers and Buijink (2005); Dumontier and Raffournier (1998); El-Gazzar et al. (1999)), we do not use a traditional logistic model as the firm-level observations within one country are not independent. Therefore, we estimate Rogers (1993) standard errors, which are White standard errors adjusted to take into account possible correlation within a cluster, in this case within a country (Petersen (2005); Rogers (1993); Williams (2000)). ${ }^{16}$ The model looks as follows:

$$
\begin{aligned}
& \log \left(P_{i j} / 1-P_{i j}\right)=\alpha+\beta_{1} L A W 2001_{j}+\beta_{2} C G I_{j}+\beta_{3} C G I_{j} * L A W 2001_{j} \\
& +\beta_{4} D I S T_{-} I F R S_{j}+\beta_{5} M A R K E T_{-} C A P_{j} \\
& +\beta_{6} E M_{j}+\beta_{7} S I Z E_{i j} \\
& +\beta_{8} A U D I T O R_{i j}+\beta_{9} \text { FINANCIAL_IND } D_{i j} \\
& +\beta_{10} L I S T \text { INGS } S_{i j} \\
& +\beta_{11} \text { OWNERSHI } P_{i j}+\beta_{12} \text { CAPITAL_INT } i j \\
& +\beta_{13} G R O W T H_{i j} \\
& +\beta_{14} L E V E R A G E_{i j}+\beta_{15} P E_{i j}+\beta_{16} M T B V_{i j}+\varepsilon_{i j}
\end{aligned}
$$

With $\mathrm{i}=$ company and $\mathrm{j}=$ country.

16 Reliance on the Rogers (1993) standard errors reduces the estimation error but does not eliminate it as the number of clusters (i.e. countries) in our paper is rather small $(<10)$ (Petersen (2005)). However, we also performed the regression with dummy variables for the countries (see section 5.3), which is another method to take into account country variation. Our results stay robust. 
The ratio of $\log \left[P_{i j} / 1-P_{i j}\right]$ is the log odds ratio or logit of the probability that company $i$ in country $j$ has adopted IFRS in 2001. The base category of the dependent variable is when a company is using local GAAP $\left(\operatorname{IFRS}_{i j}=0\right)$. We include as test variables our corporate governance index $\left(\mathrm{CGI}_{j}\right.$ ) (first hypothesis), our law index (LAW2001 ${ }_{j}$ ) (second hypothesis), and an interaction term between these two variables (third hypothesis). Positive values on the coefficients indicate that the odds of using IFRS increase as the values of the independent variables increase. The fourth hypothesis is tested through a Wald test on the difference in the size of the coefficients $\beta_{1}$ and $\beta_{2}$.

Next to the test variables, we include in our regression three country control variables. First of all, we introduce a proxy for the distance between local accounting standards and IFRS (DIST_IFRS ${ }_{j}$ ) based on Street (2002). This variable gives an indication of the number of adjustments an average company has to make to its financial reporting in order to comply with IFRS. ${ }^{17}$ The higher this variable, the more costly the switch to IFRS and therefore we expect to find a negative sign for this control variable.

Secondly, we include a measure of earnings management at the country level $\left(\mathrm{EM}_{j}\right) .{ }^{18}$ This variable measures the extent to which insiders behave opportunistically under the local accounting standards. When the level of earnings management under local accounting standards is high, insiders can extract a lot of private benefits without being discovered. As under IFRS the possibility to manage earnings, and thus to extract private benefits, is severely reduced, companies in countries with a high level of earnings management have a lower incentive to switch to IFRS. So we predict a negative sign.

Finally, we introduce in our model a measure for the size of the capital market, namely total market capitalization of listed companies as a percentage of GDP (MARKET_CAP ${ }_{j}$ ). ${ }^{19}$ Companies in countries with large capital markets have a large investor base in their home market and do not need to use international accounting standards to tap into other markets to obtain sufficient equity funding.

Next to the country control variables, we also introduce some company control variables. First, we include company size $\left(\mathrm{SIZE}_{i}\right)$. Larger companies have smaller information production costs (Lang and Lundholm (1993)) and lower costs of competitive disadvantage associated with their disclosures (Meek and Roberts (1995)). We measure size by the natural logarithm of market value of equity.

17 It is based on approximately 80 accounting measures and disclosures (Street (2002)).

18 This variable is developed by Leuz et al. (2003) and is an aggregate score of four earnings management measures for the period between 1990 and 1999. The earnings management measures reflect both the level and variability of the reported earnings. They cover the extent of smoothing, the magnitude of accruals and small loss avoidance based on Burgstahler and Dichev (1997).

19 We obtained this data from the World Bank. 
A second company control variable is the presence of a big-five auditor $\left(\mathrm{AUDITOR}_{i}\right.$ ). This variable is assumed to have a positive effect on the early adoption of IFRS as large audit firms may stimulate companies to disclose more information (Raffournier (1995)). Big-five audit firms are also more experienced in the application of IFRS (Dumontier and Raffournier (1998); Murphy (1999)).

Third, we introduce a variable indicating whether or not the company is a financial institution (FINANCIAL_IND ${ }_{i}$ ) based on the two-digit SICcodes. Financial institutions will postpone the adoption of IFRS as in 2001 the accounting standards that are particularly aimed at financial institutions, namely IAS 32 and IAS 39, were not yet endorsed by the EC.

Next, we introduce the variable LISTINGS $_{i}$ measuring the number of foreign stock exchanges a company is listed on. Companies that are listed on multiple stock exchanges have to comply with more stock exchange requirements (Cuijpers and Buijink (2005); Meek and Roberts (1995)). Thus, these companies can be expected to disclose more. Companies listed on multiple exchanges also have many foreign investors and IFRS is specifically aimed at satisfying the needs of these investors (El-Gazzar et al. (1999)).

We also add a measure of ownership concentration (OWNERSHIP $)_{i}$ ). This variable is calculated as the ratio of closely held share ${ }^{20}$ over common shares outstanding. We hypothesize a negative sign for this variable. Companies with wide ownership diffusion have high potential information asymmetries and high agency costs, resulting in more demands for firm-specific information (Cuijpers and Buijink (2005)). As a consequence, they have an incentive to respond to these demands by switching to IFRS as this can lower their cost of capital (Cohen (2004); Raffournier (1995)).

The next two company control variables capture the proprietary costs of companies. Models such as Dye (1986) and Hayes and Lundholm (1996) argue that the probability of disclosure decreases as the associated proprietary costs increase. By switching to IFRS, companies reveal more proprietary information. Hence, companies with large proprietary costs will not adopt IFRS until it becomes mandatory. We include two variables, namely CAPITAL_INT $i$, which is the ratio of property, plant and equipment over total assets, and $\mathrm{GROWTH}_{i}$, which measures the growth opportunities of companies. High capital intensity is generally interpreted as a major barrier to entry (Piotroski (2003)) as new entrants have to make large investments, which lowers the proprietary costs of information. In contrast, companies with high future growth opportunities have to preserve these future opportunities and protect them from possible entrants. We measure future growth opportunities by the sales growth of the company over 2001, based on Cohen (2004).

20 These include shares held by officers, directors and their immediate family, shares of the company held by another corporation, shares held by pension or benefit plans and shares held by individuals who hold $5 \%$ or more of the outstanding shares. 
The following variable, LEVERAGE $i$, may proxy for the governance structure of a company (Dumontier and Raffournier (1998); Meek and Roberts (1995); Cohen (2004)) but also for the amount of equity financing (El-Gazzar et al. (1999); Murphy (1999)). As a proxy for the governance structure, we would assume a positive coefficient. As highly levered firms have higher agency costs, these companies are more likely to adopt IFRS to reduce these costs. On the other hand, if leverage is used as a proxy for the financing structure of a company, we would assume a negative coefficient. Under this reasoning, companies with a low leverage are more dependent on equity financing and are hence more likely to increase disclosure to satisfy the information demands of the capital market. We measure this variable as the ratio of long-term debt over total assets, but we do not predict the sign of this variable.

Finally, we include two market performance measures, namely price-toearnings-per-share ratio $\left(\mathrm{PE}_{i}\right)$ and market-to-book-value $\left(\mathrm{MTBV}_{i}\right)$. Profitable, well-run companies have incentives to distinguish themselves from less profitable firms in order to raise capital on the best available terms. One way to do this is through voluntary disclosure (Foster (1986)).

An overview of the variables can be found in Table 3.

\section{EMPIRICAL RESULTS}

\subsection{Univariate results}

As the main purpose of this paper is to investigate the association between the institutional environment and the decision to adopt IFRS, it is interesting to test first whether a significant relation exists between the countries and the fraction of companies that use IFRS in 2001. The chisquare statistic (not reported) indicates that a highly significant association $(p<0.001)$ exists between countries and the fraction of companies using IFRS. Austria and Germany have more companies than expected following IFRS, while the opposite holds for Belgium, Denmark, France, Italy and the Netherlands. So differences in the early adoption of IFRS across countries seem to be related with dissimilarities in their institutional environment.

\subsection{Multivariate results}

The results of the logistic regression with robust standard errors are presented in Table $4 .^{21}$ The pseudo $R^{2}$ indicates that the model is relatively well

21 We computed the Variance of Inflation Factors (VIFs) in order to search for problems of multicollinearity. The VIFs are all below 7.50 for the country variables and below 2.40 for the company variables. So no problems of multicollinearity will arise in our regressions as the VIFs are below 10 . 


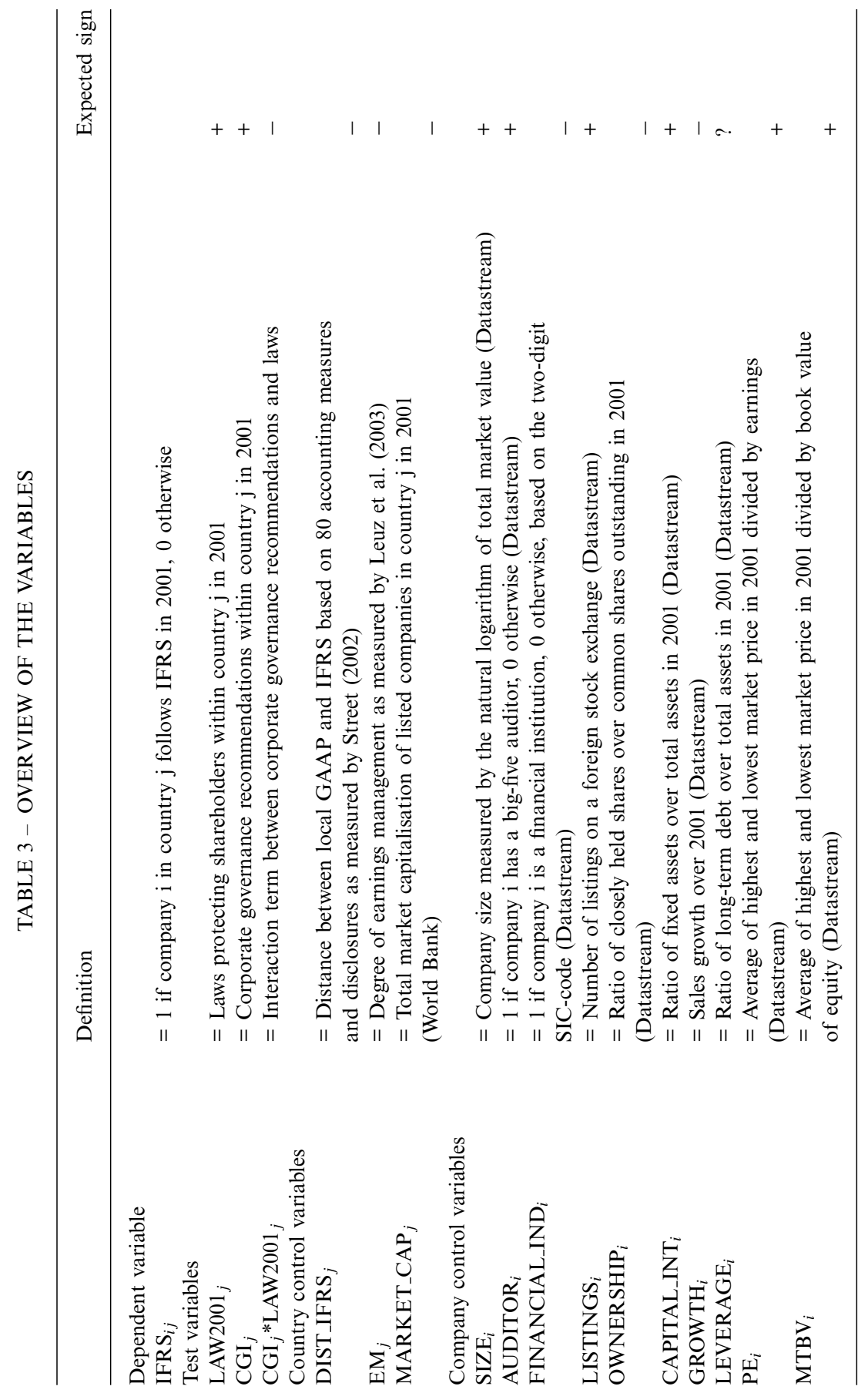


specified, as it explains about $32 \%$ of the variance in IFRS adoption. ${ }^{22}$ The Likelihood ratio statistic shows that our model has significant explanatory power. Compared to a naïve classification rule that would classify companies randomly into categories, our model classifies almost $94 \%$ of the observations correctly if we use a cut-off rate of $50 \%$. However, as we have only a very small number of companies using IFRS in 2001, it is more appropriate to use a cut-off rate equal to the sample frequency, i.e. $7 \%$. The results show that our model still does a good job as it classifies $78 \%$ of the observations correctly, which is well above the $50 \%$ of a random classification.

With respect to the significance of the individual variables, the results show that strong laws protecting shareholders (LAW2001 $j$ ) encourage companies to comply early with IFRS $(\mathrm{t}=23.65)$. We also find that corporate governance recommendations $\left(\mathrm{CGI}_{j}\right)$ are positively associated with the adoption of IFRS $(\mathrm{t}=20.89)$. These results are consistent with our first two hypotheses and indicate that in countries with weak laws protecting shareholders and few corporate governance recommendations there is a large loss of private benefits associated with IFRS adoption.

We run a Wald test on the coefficients of our corporate governance and law index to test whether they are significantly different from each other. Surprisingly, we fail to find that they are significantly different $(p=0.796)$ and thereby the third hypothesis is not confirmed. This indicates that corporate governance recommendations have an equally strong impact on the adoption of IFRS as laws protecting shareholders.

Next, we find that the interaction effect between laws and recommendations is significant at the $1 \%$ level $(\mathrm{t}=-20.23)$ and has a negative coefficient. This is consistent with our fourth hypothesis: in countries with strong corporate governance recommendations but weak laws, corporate governance recommendations become more important.

The results with regard to the country control variables confirm our expectations. We find that as the distance between local GAAP and IFRS increases, early adoption of IFRS decreases. Secondly, our results show that more earnings management under local GAAP results in a lower likelihood of adopting IFRS. Companies in countries with a lot of accounting flexibility tend to safeguard their private benefits by postponing the changeover to IFRS. Thirdly, our results indicate that as the size of the capital market increases, companies stick to their local accounting standards. In countries with large equity markets, companies have less need to switch to international accounting standards to tap into other markets to obtain sufficient equity funding.

22 In logistic regressions, there is no true $R^{2}$ value as there is in OLS regressions. However, some measures have been developed that have an analogous interpretation. SAS calculates Nagelkerke's pseudo $R^{2}$ (Nagelkerke (1991)). Prior studies find a pseudo $R^{2}$ of about 18\% (Ashbaugh (2001); Ashbaugh and Pincus (2001); Cuijpers and Buijink (2005)). 
TABLE 4 - MODEL ESTIMATES OF THE LOGISTIC REGRESSION ${ }^{a}$

\begin{tabular}{|c|c|c|}
\hline Parameter & Estimate & t-stat \\
\hline Intercept & -0.84 & -0.10 \\
\hline $\begin{array}{l}\text { Test variables } \\
{\text { LAW } 2001_{j}} \\
\text { CGI }_{j} \\
\text { CGI }_{j}{ }^{*}{\text { LAW } 2001_{j}}_{j}\end{array}$ & $\begin{array}{r}55.14^{* * *} \\
54.43^{* * *} \\
-83.69^{* * *}\end{array}$ & $\begin{array}{r}23.65 \\
20.89 \\
-20.23\end{array}$ \\
\hline $\begin{array}{l}\text { Country control variables } \\
\text { DIST_IFRS }_{j} \\
\text { EM }_{j} \\
\text { MARKET_CAP }_{j}\end{array}$ & $\begin{array}{l}-0.70^{* * *} \\
-0.57^{* * *} \\
-0.08^{* * *}\end{array}$ & $\begin{array}{l}-25.24 \\
-15.02 \\
-24.23\end{array}$ \\
\hline $\begin{array}{l}\text { Company control variables } \\
\text { SIZE }_{i} \\
\text { AUDITOR }_{i} \\
\text { FINANCIAL_IND }_{i} \\
\text { LISTINGS }_{i} \\
\text { OWNERSHIP }_{i} \\
\text { CAPITAL_INT }_{i} \\
\text { GROWTH }_{i} \\
\text { LEVERAGE }_{i} \\
\text { PE }_{i} \\
\text { MTBV }_{i}\end{array}$ & $\begin{array}{c}0.36^{* * *} \\
0.91^{* * *} \\
-1.19^{* * *} \\
0.05^{*} \\
-0.94^{* * *} \\
-0.20 \\
1.18 \\
0.72 \\
0.99 \\
0.94\end{array}$ & $\begin{array}{r}3.84 \\
7.96 \\
-10.28 \\
1.82 \\
-5.14 \\
-0.02 \\
0.99 \\
0.39 \\
0.84 \\
0.97\end{array}$ \\
\hline $\begin{array}{l}\text { Observations } \\
\text { Pseudo } \mathrm{R}^{2} \\
\text { Likelihood ratio }(\text { Chisq) } \\
\text { Correctly classified } \text { (cut-off }=0.5 \text { ) } \\
\text { Correctly classified (cut-off }=0.07 \text { ) }\end{array}$ & $\begin{array}{l}1563 \\
31.79 \% \\
250.55^{* * *} \\
93.60 \% \\
78.25 \%\end{array}$ & \\
\hline
\end{tabular}

${ }^{a}$ The dependent variable is the logit of IFRS adoption in 2001 The regression is performed with clustered robust standard errors (Rogers (1993)) to control for within country-correlation.

*** significant at $1 \%$ level,

**significant at $5 \%$ level,

*significant at $10 \%$ level

For the company control variables we find that large, non-financial companies with a Big Five auditor and that are listed on more stock exchanges have a higher rate of early compliance with IFRS. Furthermore, as expected, companies with a low ownership concentration are more likely to adopt IFRS before it is mandatory. However, contrarily to prior studies, we do not find that proprietary costs are important explanatory variables. Also the coefficients on sales growth, leverage, price-earnings ratio and market-to-book value are insignificant.

As an extension to the basic model, the different categories of the corporate governance index (general principles, board of directors, board 
committees, shareholders' rights, and disclosure) are introduced separately into the model. We also include an interaction variable between the subcategory and the law index. A similar analysis is repeated for the categories of our law index (board of directors, shareholders' rights, and disclosure). For brevity reasons, we do not report the results of these regressions. We find, for our corporate governance categories, that strong recommendations with regard to the board of directors, the board committees, and disclosure encourage the adoption of IFRS. Surprisingly, extensive recommendations with respect to shareholders do not seem to have an impact on the likelihood of adopting IFRS. Concerning the categories of our law index, we find that all three categories, namely board of directors, shareholders and disclosure, are positively related with the early adoption of IFRS. This suggests that the protection of shareholders' rights can only be achieved through hard laws. In other words, corporate governance recommendations can not substitute completely for laws. There are still some areas in which mandatory investor protection is needed in order to reduce the extraction of private benefits.

\subsection{Robustness checks}

We perform some robustness checks with regard to the country variables. First, we recompute the scores of our corporate governance and law index without rescaling the scores on the categories. So the total score on the indices is equal to the sum of the scores on the principles. We find that our results are robust. Second, we run our basic regression without the country variables but with 6 dummy variables for the countries. We use Germany as our base country. We find that, compared to Germany, only Austria has a positive impact on IFRS adoption. Italy has the most negative impact on IFRS adoption. Finally, we use the original shareholder protection index developed by La Porta et al. (1998) instead of our own extended and updated index. Our results still hold, but the $p$-values on the law index and the interaction variable become slightly less significant, indicating that our own law index has more explanatory power.

We also perform some sensitivity checks with regard to the company control variables. First, the size of a company is alternatively measured by the natural logarithm of total assets and of sales. These alternative specifications do not alter our findings. The number of listings is also specified differently. We measure this variable alternatively as an indicator variable indicating whether or not a company is listed on another stock exchange that allows the use of IFRS. We also measure this variable as an indicator variable indicating whether or not a company is listed on a stock exchange outside the EU. The $p$-value is the lowest and becomes marginally significant for the variable measuring a listing outside the EU. 
To tackle the possible problem of omitted variables in the model, we perform two additional analyses: a matched sample and the use of random and fixed effects models. Instead of using all companies that report according to local accounting standards, we match the companies using IFRS with companies using local GAAP on the basis of country, size and industry. We find that our results hold. Secondly, we run both a country fixed and a country random effects model. In doing so, we remove the unobserved effect at country level from the error term of the regression. Based on the Hausman test, the random effects model appears to be the appropriate specification, which indicates that the unobserved effects are not correlated with the other explanatory variables. In both specifications, our results hold. These additional analyses suggest that our findings are probably not influenced by omitted variable bias.

\section{CONCLUSION}

The purpose of this paper is to explain the early adoption of IFRS using an insider cost perspective. As IFRS adoption is associated with an increase in disclosure and a reduction in accounting choices, it leads to less managerial discretion and a loss of private benefits for company insiders. In this study, we argue that the degree to which insiders have to give up private benefits by adopting IFRS depends on characteristics of the institutional environment. We investigate, besides the level of legal investor protection, also a characteristic of the institutional environment not yet studied, namely corporate governance recommendations.

Our results reveal that IFRS adoption depends on the level of investor protection. Companies refrain from adopting IFRS before it becomes mandatory in 2005 because of opportunistic behaviour by management in countries with weak investor protection. In these countries, the costs of adopting IFRS are perceived by company insiders as higher due to the loss of private benefits. In contrast, strong laws protecting investors as well as extensive corporate governance recommendation limit private benefits of control, thereby reducing the costs of switching to IFRS for insiders. Furthermore, we find that corporate governance recommendations have the same impact on IFRS adoption as hard laws and are able to compensate for the negative impact of weak laws. In other words, corporate governance can effectively reduce the conflict of interest between insiders and outsiders. However, we also find that for some specific shareholder rights, such as voting rights and rights of the general meeting, hard laws are needed in order to effectively constrain the extraction of private benefits.

In summary, the level of investor protection appears to be crucial for restraining managerial opportunism, as managers determine the amount and quality of the information they provide to capital markets on the basis of their loss of private benefits of control. As a consequence, the mandated 
adoption of IFRS in 2005 is justified as it reduces the amount of private benefits insiders can extract, especially in countries with weak protection of shareholders. Therefore, investors do benefit from the mandated adoption of IFRS. Those benefits would not have been obtained if the adoption of IFRS was left to the choice of insiders.

A caveat of this study certainly is that the countries under study are all civil law countries. An extended study using a wider variety of countries that differ more in terms of economic development and level of regulation would be interesting.

\section{APPENDIX}

TABLE A1 - STRUCTURE OF THE CORPORATE GOVERNANCE INDEX

\section{GENERAL PRINCIPLES}

I. Legal basis and compliance (1)

1. Comply-or-explain principle

II. Scope (1)

2. Encouraged to all companies

Yes / No

Yes / No

\section{BOARD OF DIRECTORS}

III. Mission of the board (5)

3. Shareholder value maximization

4. Long-term viability of the company

5. Good relationship with stakeholders

6. Effective monitoring of management

7. Compliance with laws

IV. Key functions of the board (6)

8. Guide corporate strategy

9. Monitor and replace key executives

10. Review remuneration

11. Manage potential conflicts of interest

12. Guard integrity of financial reporting

13. Increase effectiveness of governance practices

Yes / No

Yes / No

Yes / No

Yes / No

Yes / No

Yes / No

Yes / No

Yes / No

Yes / No

Yes / No

Yes / No

Yes / No

None / minimum number / majority

None / minimum number / majority

Yes / No

Yes / No

Yes / No

Yes / No 
TABLE A1 - (continued)

VII. Key functions of the committees (7)

20. Appointment committee: propose appointment of directors

21. Remuneration committee: recommend remuneration for directors

22. Audit committee: report to the board

23. Audit committee: hear the company auditors

24. Audit committee: ensure appropriateness and consistency of accounting policies

25. Audit committee: verify accuracy of internal procedures

26. Audit committee: appoint auditor and determine audit fee

VIII. Independence of the committees (6)

27. Appointment committee: non-executive directors

28. Appointment committee: independent directors

29. Remuneration committee: non-executive directors

30. Remuneration committee: independent directors

31. Audit committee: non-executive directors

32. Audit committee: independent directors

\section{SHAREHOLDERS}

IX. Shareholders' protection (4)

33. Equal treatment of shareholders

34. One share/one vote

35. No anti-takeover devices

36. Proxy voting allowed

$X$. General meeting (4)

37. Select new directors

38. Participate in decisions concerning fundamental changes

39. Decide on distribution of profits

40. Ask questions

\section{DISCLOSURE}

XI. Quality (2)

41. Use high quality accounting standards

42. Audited by an independent auditor
Yes / No

Yes / No

Yes / No

Yes / No

Yes / No

Yes / No

Yes / No

None / minimum number / majority

None / minimum number / majority

None / minimum number / majority

None / minimum number / majority

None / minimum number / majority

None / minimum number / majority

\author{
Yes / No \\ Yes / No \\ Yes / No \\ Yes / No \\ Yes / No \\ Yes / No \\ Yes / No \\ Yes / No
}

Yes / No

Yes / No 
TABLE A1 - (continued)

XII. Timing (1)

43. Timely disclosure of relevant information

Yes / No

XIII. Contents (7)

44. Financial situation

Yes / No

45. Performance

Yes / No

46. Ownership

Yes / No

47. Governance

Yes / No

48. Relevant interests of directors

Yes / No

49. Composition of the board

Yes / No

50. Remuneration of key executives

Yes / No

TABLE A2 - STRUCTURE OF THE LAW INDEX

\section{BOARD OF DIRECTORS}

I. Responsibilities of the board (6)

1. Probity of financial statements

Yes / No

2. Monitor management

Yes / No

3. Guide corporate strategy

4. Guard compliance with laws and regulations

Yes / No

5. Fiduciary duty towards shareholders

Yes / No

6. Avoid conflicts of interests

Yes / No

II. Independence of the board (3)

7. Separation of chairman and CEO

Yes / No

8. Non-executive directors

Yes / No

9. Independent directors

Yes / No

Yes / No

\section{SHAREHOLDERS}

III. Shareholders' protection (9)

10. Proxy voting allowed

Yes / No

11. Pre-emptive right to new issues

Yes / No

12. One share/one vote

13. Equal treatment of shareholders

Yes / No

14. Anti-takeover devices prohibited

Yes / No

15. Shares not blocked before meeting

Yes / No

16. Cumulative voting allowed

Yes / No

17. Oppressed minorities mechanism installed

Yes / No

18. Percentage needed to call an extraordinary GM

Yes / No

IV. General Meeting (7)

19. Ask questions

Yes / No

20. Submit proposals

21. Decide on remuneration of directors

Yes / No

Yes / No

22. Select directors

Yes / No

23. Decide on distribution of profits

Yes / No

24. Appoint statutory auditor

Yes / No

25. Agree on fundamental changes

Yes / No

Yes / No 
TABLE A2 - (continued)

\section{DISCLOSURE}

\section{Quality (1)}

26. Audited by an independent auditor

Yes / No

VI. Contents (1)

27. Remuneration

Yes / No

\section{REFERENCES}

Ali, A. and L. Hwang (2000), 'Country-specific Factors Related to Financial Reporting and the Value Relevance of Accounting Data,' Journal of Accounting Research, 38(1), pp. 1-21.

Ashbaugh, H. (2001), 'Non-US Firms' Accounting Standards Choice,' Journal of Accounting and Public Policy, 20(2), pp. 129-153.

Ashbaugh, H. and M. Pincus (2001), 'Domestic Accounting Standards, International accounting standards and the predictability of earnings,' Journal of Accounting Research, 39(3), pp. 417-434.

Ball, R., S. Kothari and A. Robin (2000), 'The Effect of International Institutional Factors on Properties of Accounting Earnings,' Journal of Accounting and Economics, 29, pp. $1-51$.

Beiner, S., W. Drobetz, M. Schmid and H. Zimmermann (2006), 'An Integrated Framework of Corporate Governance and Firm Valuation,' European Financial Management, 12(2), pp. 249-283.

Benos, E. and M. Weisbach (2004), 'Private Benefits and Cross-listings in the US,' Working paper, University of Illinois, Ib.

Black, B. (2001), 'Does Corporate Governance Matter: A Crude Test Using Russian Data,' University of Pennsylvania Law Review, 149(6), pp. 2131-2150.

Black, B., H. Jang and W. Kim (2006), 'Does Corporate Governance Predict Firm's Market Values? Evidence from Korea,' Journal of Law, Economics and Organisation, 22(2), pp. 366-413.

Burgstahler, D. and I. Dichev (1997), 'Earnings Management to Avoid Earnings Decreases and Losses,' Journal of Accounting and Economics, 24(1), pp. 99-129.

Coffee, J. (2001), 'Do Norms Matter? A Cross-country Examination of the Private Benefits of Control,' Columbia Law School Working Paper No. 183.

Cohen, D. (2004), 'Quality of Financial Reporting Choice: Determinants and Economic Consequences,' Working paper, Northwestern University.

Council of the EC (1978), 'Fourth Council Directive 78/660/EEC of 25 July 1978 based on Article 54 (3) (g) of the Treaty on the Annual Accounts of Certain Types of Companies,' Document 378L0660, Official Journal L 220.

Council of the EC (1983), 'Seventh Council Directive 83/349/EEC of 13 June 1983 based on the Article 54 (3) (g) of the Treaty on Consolidated Accounts,' Document 383L0349, Official Journal L 193.

Cuijpers, R. and W. Buijink (2005), 'Voluntary Adoption of Non-local GAAP in the European Union: a Study of Determinants and Consequences,' European Accounting Review, 14(3), pp. 487-524. 
Doidge, C. (2005), 'What is the Effect of Cross-listing on Corporate Ownership and Control?,' Working paper, University of Toronto, Toronto.

Drobetz, W., A. Schillhofer and H. Zimmermann (2003), 'Corporate Governance and Expected Stock Returns: Evidence from Germany,' ECGI Finance Working paper No. 11/2003.

Dumontier, P. and B. Raffournier (1998), 'Why Firms Comply Voluntarily with IAS: an Empirical Analysis with Swiss Data,' Journal of International Financial Management and Accounting, 9(3), pp. 216-245.

Dyck, A. and L. Zingales (2004), 'Private Benefits of Control: an International Comparison,' Journal of Finance, 59(2), pp. 537-600.

Dye, R. (1986), 'Proprietary and Nonproprietary Disclosures,' Journal of Business, 59(2), pp. 331366.

El-Gazzar, S., P. Finn and R. Jacob (1999), 'An Empirical Investigation of Multinational Firms' Compliance with International Accounting Standards, International Journal of Accounting, 34(2), pp. 239-248.

European Commission (2000), 'Communication from the Commission to the Council and the European Parliament: EU Financial Reporting Strategy: The Way Forward,' COM(2000) 359 final.

European Commission (2002), 'Comparative Study of Corporate Governance Codes Relevant to the European Union and its Member States,' www.europa.eu.int.

European Corporate Governance Network (ECGN) (1997), 'The Separation of Ownership and Control: A Survey of 7 European Countries,' www.ecgn.org.

Ferrell, A. (2004), 'The Case for Mandatory Disclosure in Securities Regulation around the World,' Harvard John M. Olin Discussion Paper Series 10/2004, Cambridge.

Foster, G. (1986), Financial Statement Analysis, Prentice Hall, London.

Gompers, P., J. Ishii and A. Metrick (2001), 'Corporate Governance and Equity Prices,' Quarterly Journal of Economics, 116(1), pp. 107-155.

Hayes, R. and R. Lundholm (1996), 'Segment Reporting to the Capital Market in the Presence of a Competitor,' Journal of Accounting Research, 34(2), pp. 261-279.

Hung, M. (2001), 'Accounting Standards and Value Relevance of Earnings: An International Analysis,' Journal of Accounting and Economics, 30, pp. 401-420.

La Porta, R., F. Lopez-de-Silanes and A. Shleifer (2004), 'What Works in Securities Laws?', Working paper, Darthmouth College.

La Porta, R., F. Lopez-de-Silanes, A. Shleifer and A. Vishny (1997), 'Legal Determinants of External Finance,' Journal of Finance, 52, pp. 1131-1150.

La Porta, R., F. Lopez-de-Silanes, A. Shleifer and A. Vishny (1998), 'Law and Finance,' Journal of Political Economy, 106(6), pp. 1113-1155.

Lang, M. and R. Lundholm (1993), 'Cross-sectional Determinants of Analyst Ratings of Corporate Disclosures,' Journal of Accounting Research, 31(2), pp. 246-271.

Leuz, C., D. Nanda and P. Wysocki (2003), 'Earnings Management and Investor Protection: an International Comparison,' Journal of Financial Economics, 69(3), pp. 505-527.

Leuz, C. and R. Verrecchia (2000), 'The Economic Consequences of Increased Disclosure,' Journal of Accounting Research, 38, pp. 91-124.

Meek, G. and C. Roberts (1995), 'Factors Influencing Voluntary Annual Report Disclosures by U.S., U.K. and Continental European Multinational Corporations,' Journal of International Business Studies, 26(3), pp. 555-573. 
Murphy, A. (1999), 'Firm Characteristics of Swiss Companies that Utilize International Accounting Standards,' The International Journal of Accounting, 34(1), pp. 21-131.

Nagelkerke, N. (1991), 'A Note on General Definition of the Coefficient of Determination,' Biometrica, 78(3), pp. 691-692.

Nenova, T. (2003), 'The Value of Corporate Voting Rights and Control: a Cross-country Analysis,' Journal of Financial Economics, 68(3), pp. 325-351.

Organisation for Economic Co-operation and Development (OECD) (1999), 'OECD Principles of Corporate Governance,' Doc. No. SG/CG(99)5.

Petersen, M. (2005), 'Estimating Standard Errors in Finance Panel Data Sets: Comparing Approaches,' Working paper, Northwestern University.

Piotroski, J. (2003), 'Segment Reporting Fineness and the Precision of Investors' Beliefs,' Working paper, University of Chicago.

PricewaterhouseCoopers (2002), '2005 - Ready or not: IAS in Europe - the Views of over 650 CFOs,' www.pwcglobal.com.

Raffournier, B. (1995), 'The determinants of voluntary financial disclosure by Swiss listed companies,' European Accounting Review, 4(2), pp. 261-280.

Rogers, W. (1993), 'Regression Standard Errors in Clustered Samples,' Stata Technical Bulletin, 13, pp. 19-23.

Street, D. (2002), 'GAAP 2001 - Benchmarking National Accounting Standards against IAS: Summary of Results,' Journal of International Accounting, Auditing and Taxation, 11(1), pp. 77-90.

Williams, R. (2000), 'A Note on Robust Variance Estimation for Cluster-correlated Data,' Biometrics, 56(2), pp. 645-646.

Zmijewski, M. (1984), 'Methodological Issues Related to the Estimation of Financial Distress Prediction Models,' Journal of Accounting Research, 22, pp. 59-82. 